\title{
The Exceptional Election of 2008: Performance, Values, and Crisis
}

\author{
James E. Campbell \\ University at Buffalo, SUNY \\ Presidential Studies Quarterly, forthcoming.
}

\begin{abstract}
This research examines influences on the 2008 presidential election. With an unpopular Republican president, an unpopular war, and a slumping economy, 2008 looked to be a good year for the Democrats. On the other hand, open seat elections have been historically close and less affected by retrospective considerations. Moreover, partisanship, ideological polarization, and contested nominations in both parties inclined the electorate to an even division. McCain's more centrist record and Obama's race also seemed to favor the Republicans. Taken together, these factors set the stage for a closely decided election. It was shaping up in the polls that way until the Wall Street meltdown hit in mid-September. It was the "game changer" that tipped the election to Obama.
\end{abstract}

\begin{abstract}
Authors's Bio
James E. Campbell is Professor and Chair of the Department of Political Science at the University at Buffalo, SUNY. Author of over sixty journal articles and book chapters about American politics, his most recent book is the second edition of The American Campaign (Texas A\&M, 2008).
\end{abstract}




\section{The Exceptional Election of 2008: Performance, Values, and Crisis ${ }^{1}$}

Bringing several years of nomination and general election campaigns to a close, more than 131 million voters cast ballots in the 2008 presidential election and elected Democrat Barack Obama over Republican John McCain. The two-party popular vote split 53.7 percent for Obama to 46.3 percent for McCain. With 365 electoral votes cast from 28 states and the District of Columbia (with one electoral vote from Nebraska) for Obama and 173 electoral votes from 22 states cast for McCain, Senator Barack Obama was elected to serve as the $44^{\text {th }}$ president of the United States and the first African-American to occupy the office.

The margin of Obama's popular vote victory ranks seventeenth among the thirty-six presidential elections since the Civil War. Sixteen margins were smaller and nineteen larger. ${ }^{2}$ Compared to recent elections, it was larger than either of President George W. Bush's victories and slightly smaller than President Bill Clinton's 1996 election. It was about the same magnitude as President Clinton's 1992 and President George H.W. Bush's 1988 popular vote margins. While the size of the 2008 winning vote margin was solid but unremarkable, neither especially close nor particularly large when set in historical perspective, the route to the electorate's verdict was exceptionally unusual.

Early readings of the fundamentals in 2008 were extremely favorable for the Democrats. An unpopular president conducting an unpopular war and presiding over a sluggish economy amounted to heavy baggage for Republicans. On this basis, it would be easy to regard 2008 as a simple retrospective election. The in-party was not doing well, so voters made the easy decision to throw them out. On closer inspection though, the weight of the baggage for the Republican candidate was somewhat exaggerated and several aspects of "the fundamentals" suggested a close election. Partisan parity, ideological polarization, an open seat election, and nomination circumstances in both parties set the stage for another tight race-not unlike the two preceding elections. The polls leading up to the parties' conventions suggested as much.

Then there were other reasons why the electorate may have looked favorably on Senator McCain. He had an unusually centrist congressional record for a Republican presidential candidate and Senator Obama had a record as a northern liberal Democrat. One might also have anticipated that Obama would face some resistence as the first black presidential candidate of a major party. The polls coming out of the parties' conventions supported the view not only of a close election, but one tilted a bit toward McCain. In the end, and what was most exceptional about this election was that it turned on the public's reaction to the financial credit crisis that struck the national economy during the campaign in mid-September. What became known as the Wall Street meltdown was the "game changer." It was the "October Surprise" that struck in midSeptember and turned the election decisively to Obama. Never before in the history of modern

presidential elections had an event like the Wall Street meltdown struck in the middle of the campaign and effectively changed the course of the election. 


\section{A Democratic Year}

Before the protracted nomination struggle between Senator Hillary Clinton and Senator Barack Obama was settled and even before the unusual Republican nomination contest drifted to Senator John McCain, the conventional wisdom was that 2008 would be a banner year for the Democrats. There was widespread unhappiness with the direction of the country during President George W. Bush's second term. Between April and July of 2008 in four Gallup polls, a mere $15 \%$ of respondents on average said that they were satisfied "with the way things are going in the United States at this time." ${ }^{3}$ The verdict about the performance of the Republican administration could hardly have been clearer or more negative. In late July, Alan Abramowitz, Thomas Mann, and Larry Sabato (2008) summarized this outlook: "It is no exaggeration to say that the political environment this year is one of the worst for a party in the White House in the past sixty years."

The fundamentals were decidedly unfavorable to the Republicans. Long before the first caucuses convened in Iowa to select delegates to the national conventions, the public had grown dissatisfied or impatient with the War in Iraq. In the months leading up to the conventions, polls showed substantial opposition to the war. Eighteen separate polls conducted by CNN/Opinion Research throughout 2007 and through July of 2008 indicated that about twice as many Americans had come to oppose the War in Iraq as support it. Despite progress in the "surge" strategy in Iraq, the war remained a political liability for Republicans. ${ }^{4}$

The economy leading into the 2008 campaign season was also bad news for Republicans. Real growth in the gross domestic product (GDP) was a negative two-tenths of a point in the fourth quarter of 2007 and only nine-tenths of a point on the positive side in the first quarter of $2008 .{ }^{5}$ The historical record indicates that the voters' expectations set a growth rate of about three percent as the politically neutral point between punishing and rewarding an in-party's economic record. Leading into the 2008 electoral season, the Republican administration had presided over half a year of economic malaise. What made economic matters worse politically was that voters were reminded of these problems every time they filled up their cars and paid their heating bills. Soaring oil prices hit voters and the economy hard throughout this period. Making matters even worse politically was President Bush's well-known Texas oil connections. Oil men are not very popular when gas prices in July 2008 had almost doubled from what they had been in early 2007 and had nearly tripled since early $2002 .{ }^{6}$

The clearest indication of the severity of the bad climate for Republicans was President Bush's anemic approval ratings. While presidents need not hold 50 percent of approval in order to win elections, they generally need ratings in the mid-40s. President Bush's approval ratings, according to Gallup, had been below 40\% since October 2006 and remained below 35\% throughout 2008. ${ }^{7}$ In the five Gallup polls conducted in the ten weeks prior to the conventions, his approval rating averaged a mere 31 percent. With less than a third of the public indicating approval of the Republican president, there was certainly good reason to think that 2008 would be a Democratic year. 


\section{Prospects for a Close Election}

There were, however, other indications that the election would be closely decided. Beyond the recent history of the controversial 2000 election and closely decided 2004 election, the broader history of open seat presidential elections was of narrowly decided contests. Table 1 presents the popular vote margins in the 35 open-seat and incumbent elections from 1868 to 2004. Elections are grouped in three categories: near dead-heats, competitive elections, and landslides. ${ }^{8}$ Near dead-heats are those in which the winning candidate received $51.5 \%$ of the twoparty vote or less. Landslides are those in which the winning candidate received more than 57\% of the two-party vote. Competitive elections are closer than landslides, but not as close as near dead-heats. As the table shows, near dead-heats are uncommon when an incumbent is in the race and common in open seat contests. Almost half of open seat elections have been near-dead heats. Near dead-heat elections are more than three times more likely without an incumbent in the race than with an incumbent. Incumbents (especially those whose party has held the White House for just one term) are not only more likely to win their elections, but more likely to win them by wide margins (Campbell 2000 and 2008, Norpoth 2008, Mayhew 2008). ${ }^{9}$ While electoral verdicts about incumbents are more likely to be decisive, open seat elections are more likely to be toss-ups.

\section{/Table 1 about here/}

Open seat elections have been close, in part, because retrospective voting is less applicable to them. Voter reactions to the previous administration's performance do not fully carry over to the next election when the incumbent is not running. Accountability is assigned partly to the in-party and partly to the president himself. Successor candidates receive only a portion of the credit or blame for the successes or failures of their predecessors (Campbell 2001, Nadeau and Lewis-Beck 2001, Norpoth 2002, Holbrook 2008, and Campbell, Dettrey, and Yin 2008). Open seat elections are, in effect, muted referenda. While Republican candidate John McCain would carry considerable baggage into the election from the widely perceived failings of the Bush presidency, it would be far lighter than the burden that President Bush would have shouldered had he been the Republican candidate.

Beyond the general tendency of open seat elections to be closely decided, the near parity in partisanship in recent elections coupled with the increased ideological polarization of the electorate increased the odds of a closely and intensely fought election. Figure 1 displays the percentages of reported voters holding Democratic or Republican party identifications in elections from 1952 to 2008 . Following Keith et. al. (1992), independent leaners are counted as partisans. The NES data have been reweighted to match the actual turnout rate of the voting eligible population and the vote division of actual voters. The pure independent portion of the electorate, ranging from five to ten percent of voters, is the residual unplotted category.

/Figure 1 about here/

As the figure shows, the balance of party identification strongly favored Democrats from the 1950 s to the 1970 s and then shifted to near parity in elections since the mid-1980s. The staggered realignment of the parties from the 1960s to the 1990s sorted ideologues into two more 
evenly balanced and ideologically homogeneous parties, a more conservative Republican Party and a more liberal Democratic Party (Campbell 2006a, Paulson 2007, Fiorina 2006). While presidential voting habits changed in the late 1960s, changes in party identification lagged behind (Norpoth 1987). When they did change, they did not indicate a new majority party, but a new competitive party system. Democrats had been the majority party by a wide margin, but that had changed. In elections from 1984 to 2004, Democrats outnumbered Republicans by only two to three percentage points among reported voters. About 47.3 percent of voters in this period identified as Democrats and about 44.8 percent as Republicans (medians of NES data reweighted to the actual vote). As the figure shows, Democrats gained ground in party identification among voters in 2008 (increasing to 50.3 percent, about where they stood in 1996). Nevertheless, even with Democratic gains, party identification remained at fairly competitive levels in $2008 .{ }^{10}$

Though Democrats had an edge in partisanship in 2008, Republicans had an edge in ideology. ${ }^{11}$ Since 1992, about 36 percent of voters have professed a conservative ideological inclination compared to only about 22 percent who claimed a liberal perspective. According to NES data (reweighted to the actual vote), liberal ranks increased slightly in 2008 (24 percent), but they remained greatly outnumbered by self-described conservatives ( 36 percent). The NES's thermometer scales also indicated a decidedly conservative bent to the electorate, with $43 \%$ percent of voters more favorably inclined to conservatives than liberals and only $29 \%$ expressing more liberal affections (the remaining 28\% were neutral). Even though Stimson's public mood index indicated an increasing desire for a less conservative government than what the public perceived in the Bush administration, the nation remained clearly center-right in its political orientations. ${ }^{12}$ With the realignment leaving the parties more ideologically homogenous, the Republican party stood to gain from this conservative plurality as the more conservative option of the major parties.

The rough balance in the partisan and ideological predispositions of the electorate was particularly important to the election because both partisanship and ideology had become increasingly important to voters in recent years. With the realignment of the parties along ideological lines, there has been a resurgence of partisanship and in its effect on the vote (Bartels 2000, Hetherington 2001, Campbell 2008). The ideological sorting out of the realigned parties also had the effect of increasing the ideological polarization of public opinion (Abramowitz 2006, Campbell 2006b). ${ }^{13}$ In the 1970s and 1980s, about half of all voters were self declared moderates or could not declare their ideological orientations. By the 1990s, this number had dropped to about 40 percent. A majority of voters were no longer moderate. They held either liberal or conservative political perspectives and these ideological orientations became more influential in their vote choice (Abramowitz and Saunders 1998). With party identifications and ideological outlooks roughly balanced and with both exerting stronger influences on the vote, there was good reason to suppose that the election would be narrowly decided.

This balance of political predispositions played an important role in muting the effects of retrospective evaluations in the election. Its importance is evident in an examination of where President Bush lost approval between his 2004 reelection and the 2008 election. As Table 2 shows, President Bush's approval rating (as measured by Gallup) dropped 17 points from 48 
percent at the time of his reelection in 2004 to only 31 percent in July of 2008-not good news for his would-be Republican successor. However, the internals of where President Bush lost approval suggest that his low rating was not the unbearable burden it appeared to be. Most of this loss came out of the Republican party. Perhaps because of polarization, very few Democrats approved of President Bush in 2004. His ratings among Democrats barely reached double digits. There was not much Democratic support that could be lost. In contrast and also associated with polarization, President Bush enjoyed sky-high approval ratings in 2004 among his fellow Republicans (Jacobson 2007). Eventually, however, whether because of the administration's inadequate performance in dealing with the aftermath of Hurricane Katrina or its controversial immigration proposal, many of these supportive Republicans drifted away by 2008 and this sent the President's numbers into the low thirties range.

The upside for McCain was that the Republicans and some independents disgruntled with President Bush had inclinations would make them more easily won back in 2008. The many conservative Republicans disapproving of President Bush were unlikely Obama voters. This is exactly what both the exit polls and NES data later confirmed. Among the $21 \%$ of voters who "somewhat disapproved" of President Bush's job performance $(21 \%$ in the exit polls and $16 \%$ in the reweighted NES), McCain beat Obama by about two-to-one (65-31 in the exit polls and 6337 in the reweighted NES). More to the point, among voting Republican partisans who disapproved of President Bush's job performance, 80 percent voted for McCain according to NES data. Though this was some slippage from the 95 percent of the vote that McCain received from Republicans who approved of President Bush, it was considerably better than the 7 percent of the vote he received from disapproving Democrats.

The nomination battles that took place in both parties also increased the prospects of a close election. Neither party had the advantage of having a candidate coast to the nomination with an enthusiastic and unified base. Democrats were enthusiastic about their candidates, but unusually divided over whether to choose Hillary Clinton or Barack Obama as their nominee. In another exceptional aspect of the 2008 election, defying all of the conventional wisdom about front-end loading leading to a quick nomination decision, Clinton and Obama waged a protracted battle over the Democratic nomination. Despite Clinton winning many of the large population states (including New York, California, Pennsylvania, and Ohio) and nine of the final fifteen primaries, Obama did well enough in the proportional representation primaries and in the caucus system states along with the party's superdelegates to secure the nomination. Still, Clinton did not concede the nomination to Obama until June 7, more than five months after the Iowa Caucuses started the official delegate selection process. Although Clinton and Obama were ideologically quite similar, both with strong liberal credentials during their service in the Senate, the intense battle for the nomination left the party with some scars.

While the Democrats were enthusiastic about their chances though divided over their party's standard-bearer, the Republicans were neither optimistic about the election nor enthusiastic about their the nominee, John McCain. Lacking a clearly conservative candidate who could energize the party's base, McCain was able to secure the Republican nomination from a crowded field of hopefuls. With the help of independents and crossover votes in open primary 
states, by Super Tuesday (February 5), McCain pulled out to a commanding delegate lead over his closest rivals, former governors Mitt Romney of Massachusetts and Mike Huckabee of Arkansas. McCain effectively secured the nomination when Romney dropped out of the race two days later. Though Republicans settled on their nominee months before the Democrats, their nominee did not excite the base.

The long and the short of it is that neither Barack Obama nor John McCain had easy nomination campaigns. According to NES data, both McCain and Obama won about equally large majorities of the votes of partisans who cast primary ballots for their nomination rivals, but this was about ten percent less of the vote than they received from their nomination supporters. ${ }^{14}$ Neither had an easy ride to their conventions and these roughly equal troubles, though of very different natures, set the stage for what looked to be a roughly equal vote in November.

The candidates were the final factors auguring a close election. Again, the ingredients were those of an exceptional election. In Barack Obama, the Democrats nominated an inspiring, articulate, and charismatic candidate. The news media did little to hide the fact that they were entranced by him. Smitten might be a more accurate description. On the downside politically, however, was the fact that no other African-American leader had ever received the presidential nomination of a major party, much less been elected president. ${ }^{15}$ In addition, Obama had the disadvantage of being a northern liberal Democrat. While pundits would speculate about the role that race might play in the election, the ideological liability required no speculation. The history of northern liberal Democratic defeats was crystal clear: Humphrey in 1968, McGovern in 1972, Mondale in 1984, Dukakis in 1988, and Kerry in 2004.

On the Republican side, because of the candidate void on the right, Republicans nominated a moderate conservative. John McCain was a self-described maverick, virtually a bipartisan candidate. Indeed, McCain had been courted by John Kerry in 2004 to be his runningmate on the Democratic ticket. McCain had a history of breaking with his party, from campaign finance reform to working with a group of moderate Senators to block the so-called "nuclear option" on judicial nominations. Even during the campaign, McCain frequently criticized his own party and President Bush, particularly on matters of fiscal policy and earmarks.

The Senate voting records for McCain and Obama are a study in contrasts. Combining the liberal Americans for Democratic Action roll call scores with the American Conservative Union roll call scores (flipped to make them comparable) for 2006 and 2007, McCain had a rating of 24 percent liberal. ${ }^{16} \mathrm{He}$ was almost perfectly positioned between a 50 percent moderate score and a perfectly consistent conservative score. Obama, on the other hand, voted 95 percent of the time in the liberal direction. Assuming that critical swing votes are won in the political center (even somewhat right of center in modern American politics), McCain seemed much better positioned for the general election campaign.

The relative positioning of the two candidates was reflected during the campaign in a number of ways and issues. The differences were suggested in the campaigns' themes. In keeping with his centrist background, McCain's "Country First" theme emphasized national unity. 
Recognizing their greater strength on the performance dimension, Obama's "Change We Can Believe In" theme emphasized performance considerations and distrust of the past administration rather than values.

The exit polls suggested that the candidate-ideological differences made a difference in the campaign. Energy is a prime example. With both gas prices and concerns about dependence on foreign oil imports soaring, many centrists and conservatives wanted the government to expand offshore drilling for oil. The popular catch-phrase was "drill, baby, drill" and McCain's "all of the above" position on energy more closely fit national opinion than did Obama's. The exit polls found that two-thirds of voters favored expanding offshore drilling and McCain won this vote $59 \%$ to $39 \%$.

In more general terms, voters perceived McCain to be the more centrist candidate. A Gallup poll in late October indicated that $29 \%$ of respondents regarded Obama as "very liberal" while only $16 \%$ found McCain to be "very conservative." NES data indicate that more voters placed themselves closer to McCain on the ideological scale (47\%) than to Obama (40\%). In the exit polls, $42 \%$ of voters considered Obama to be "too liberal" and $89 \%$ of them voted for McCain. ${ }^{17}$ Of the $30 \%$ of voters in the exit polls saying that the candidate quality that mattered to them most was whether the candidate "shares my values," McCain beat Obama by two-to-one (65\% to $32 \%)$. In short, though Obama held a clear advantage in terms of retrospective considerations, McCain held an advantage on prospective or values considerations.

\section{Tracking the Campaign}

The anticipation of a closely decided election seemed well founded leading into the two parties' conventions in late August. Figure 2 displays McCain's percentage of the two-party support in Gallup's tracking poll of registered voters from August 1 through to Election Day. As the figure shows, though there is variation and Obama consistently held a slight lead in the polls, the race was fairly close through August especially in the weeks immediately before the conventions. Gallup's mean August pre-convention polls of registered voters (August 1 through August 24) had the race at 51.3 percent Obama to 48.7 percent McCain. The Real Clear Politics average of polls over the same period had the race at 51.7 percent Obama to 48.3 percent McCain. ${ }^{18}$ A swing of less than two points separated the candidates. If you also consider the higher propensity of registered Republicans to turn out to vote, then going into the conventions the race was a toss-up. ${ }^{19}$ Moreover, both Gallup and the Real Clear Politics average of polls had McCain closing on Obama in the days before the Democrats convened for their convention in Denver. Over the ten days leading up to the Democratic convention, Gallup's polls averaged 50.6 percent for Obama to 49.4 percent for McCain and the final two pre-convention Gallup polls had the race tied. Despite Iraq, a sluggish economy, an unpopular president, and all the elements of the Democratic year, McCain was still quite clearly in the game.

\section{/Figure 2 about here/}

In late August and early September, both parties staged successful conventions. Democrats reunified around Obama and, largely through McCain's choice of Alaska Governor 
Sarah Palin as his vice presidential candidate, Republicans became energized about their ticket as well. The net effect slightly favored the Republicans. Comparing the poll standings in the seven days prior to the Democratic convention to the seven days after the later Republican convention, McCain gained 2.6 percentage points among Gallup's registered voters, 2.3 points among the Real Clear Politics average of polls, and 1.2 in James Stimson's composite of polls. ${ }^{20}$ McCain came out of the conventions with a small lead according to the Gallup and Real Clear Politics readings, but still trailed slightly in Stimson's composite. McCain held the lead in the Gallup poll for ten days and eleven in Real Clear Politics, and this is accepting both at face value, without making any adjustment for Republicans having a consistently higher turnout rate.

The fact that McCain held a lead of any sort after the conventions is both important and exceptional, given the strong retrospective evaluations of the Democratic year. McCain's postconvention poll lead was exceptional because it defied the historical link of retrospective evaluations of the sitting president and preferences for the in-party's presidential candidate. Table 3 displays the history since 1948 of the association between presidential approval ratings in July of election years and the in-party candidate's level of support among registered voters in early September. The elections are ordered by the president's July approval rating. When the president's July approval rating has been higher than 46 percent, the in-party candidate also led in the September preference polls. Conversely, when the July approval rating has been under 46 percent, the in-party candidate trailed in the September polls-except in 2008. Despite President Bush being tied for the lowest standing in the July approval ratings, John McCain held a September poll lead. This might be dismissed if the approval rating were just shy of the 46 percent threshold, but President Bush's approval rating was fully 15 points below that; or if McCain's lead were very narrow and in only a few polls, but it was in a number of polls over at least ten days. All of the factors that made 2008 so clearly a Democratic year were not enough to establish Obama as the post-convention frontrunner.

/Table 3 about here/

There were also historical reasons to consider McCain's post-convention poll to be important to the election. In the 15 elections from 1948 to 2004, 12 had candidates with discernable leads in early September Gallup polls, a discernable lead being one in which one candidate had at least a 52 to 48 percent lead over his opponent. Eleven of these 12 poll leaders went on to win their elections. Tom Dewey in 1948 is the only candidate with a clear early September poll lead to lose his election-until 2008.

It is normally the case that convention bump effects largely dissipate and that the competitive pressures of the campaign reduce whatever lead that a candidate might hold in the early September polls. So after the conventions, there was every reason to suppose that McCain's lead in the polls would shrink and that we were in for another intensely battled election ending with a close division of the vote. Instead, the floor fell out from under the McCain campaign. How and why did this happen? 


\section{The Wall Street Meltdown}

Exceptional events happened that derailed the normal campaign and dramatically changed the course of the election. The Wall Street meltdown crisis in financial institutions hit in midSeptember, dominated the remainder of the campaign, and shifted a significant portion of the vote from McCain to Obama. It was a game changer, the final straw for many voters who had been willing to tolerate a good deal of dissatisfaction with the Republican administration up to that point.

The reasons for the Wall Street meltdown went back many years and developed slowly over time (Sowell 2009). They are too long and complicated to explain in much depth here. The basic facts were that financial institutions for a variety of reasons over many years made insufficiently secured mortgages and this fueled an unsustainable run-up in real estate prices, a real estate bubble. When energy prices soared out of control, economic growth slowed causing the real estate bubble to burst. This dealt a severe blow to the financial institutions that held the paper on the bad loans. Before the conventions, the problem seemed limited to a few isolated financial institutions (e.g., Bear Stearns), with others having some problems that they could probably weather. In early September, however, the breadth and depth of the problem became clearer. At that point, a number of huge financial institutions were on the brink of insolvency, government policy responses were uncertain, credit markets froze, and the economy was in crisis, perhaps teetering on the brink a deep recession or even a depression.

At the parties' conventions, the looming Wall Street meltdown was nowhere in sight. The issue was on neither party's radar screens. The first sign that the subprime mortgage mess amounted to something considerably more than a few isolated bankruptcies was on September 7 when the government seized control of Fannie Mae and Freddie Mac, the two governmentsponsored mortgage institutions. Eight days later, Lehman Brothers declared bankruptcy and a distressed Merrill Lynch was bought by the Bank of America. The next day, September 16, the government made an $\$ 85$ billion bailout loan to insurance giant AIG. On September 19, President Bush called the crisis "a pivotal moment for America's economy" and asked Congress to "act now to protect our nation's economic health from serious risk" (Bush 2008). The administration proposed a $\$ 700$ billion financial institutions bailout bill and Congress reconvened to consider it. On September 24, John McCain suspended his campaign to return to Washington for the bailout talks and called for the postponement of the first presidential debate, scheduled just days later. After being turned back in the initial House vote, a revised version of the $\$ 700$ billion Bipartisan Emergency Economic Stabilization Act was passed and signed by the President on October 3. Meanwhile, the crisis spread. Washington Mutual was seized by the FDIC on September 29. From September 8 to October 9, the stock market lost a quarter of its value (a 25 percent drop in the Dow Jones index and a 28 percent drop in the Standard and Poor's index).

Some election analysts have downplayed the impact of the Wall Street meltdown, interpreting it as just more bad economic news of an already weak economy (Sabato 2009, Abramowitz 2009). This was not the case. It was an unanticipated dramatic change in economic conditions, unanticipated by economic experts as well as the electorate. In mid-August, half way 
through the third quarter of 2008, the Federal Reserve Bank of Philadelphia released a survey of 47 prominent economic forecasters. These forecasters predicted a third quarter real GDP growth rate of 1.2 percent, a sluggish economy, but certainly not one in recession. Despite the fact that this forecast was made midway through the quarter being forecast and the meltdown occurring only in the last month of the quarter, the actual GDP growth rate for the quarter according to the Bureau of Economic Analysis was -.5 percent. This was nearly two points lower than the forecast made during the quarter. The difference between the predicted sluggish economy (1.2 percent growth) and the actual retracting economy (-.5 percent "negative growth" or shrinkage) is about the same magnitude of difference as between a sluggish economy (1.2 percent) and a healthy one (about 3 percent growth). The meltdown produced an unanticipated big difference in a very short period.

The Wall Street meltdown was also unanticipated by the public. Evaluations of the economy changed dramatically from before the meltdown to after it. Public evaluations of the economy before the meltdown were not good, but they dropped precipitously with the meltdown. In three Gallup polls of consumer confidence about economic conditions in August and early September, an average of 46 percent rated economic conditions as poor (the lowest rating). ${ }^{21}$ The number regarding economic conditions as poor jumped to a mean of 68 percent in two October Gallup polls conducted after the meltdown. The more than twenty point increase in poor ratings of the economy between before and after the meltdown indicate that the meltdown was not seen by Americans as just more news about a sluggish economy.

The public understood the gravity of the Wall Street meltdown. A USA Today and Gallup poll on September 24 asked respondents how they would describe "the current situation." Forty percent said that it was "the biggest financial crisis in [their] lifetime." Another 24 percent said that it was "a crisis but not the worst in [their] lifetime." Only 10 percent said it was not a major problem. An ABC-Washington Post poll on September 29 asked respondents about the potential impact of "the country's current financial situation" on the broader economy. Fifty-two said it was "a crisis." Another 43 percent said "a serious problem but not a crisis." Only five percent thought it was not a crisis or a serious problem. ${ }^{22}$

The political fallout was clear. Much of the public blamed the President and Republicans generally for the crisis. Despite President Bush's low approval ratings going into the election and the polarization of the electorate, his ratings sank even lower during the meltdown. The Gallup Poll conducted from September 5-7 indicated that only 33 percent of the public approved of the President's job performance. As low as that was, the October 3-5 Gallup Poll indicated that it had dropped another eight points to 25 percent. While a pre-meltdown September 5-7 Gallup poll indicated that the candidates were virtually tied with respect to which would better handle the economy ( $48 \%$ Obama to $45 \%$ McCain), the post-meltdown October 10-12 Gallup poll showed that Obama had opened up a big lead on the issue (53\% for Obama to $39 \%$ McCain). In a little over three weeks from September 14 (allowing some time for the convention bump to recede) to October 6, John McCain's share in Gallup's tracking poll dropped six points from 51 to 45 percent. The Real Clear Politics poll average dropped about 4.4 points over the same time. The polls in the remaining four weeks bounced around a bit without much real change. The election had been decided. 
The Wall Street meltdown was truly an exceptional event. It was an entirely unexpected crisis, not even raised as an issue in the conventions just weeks before and unanticipated by most economic experts. It is difficult to think of an unexpected event occurring during a previous campaign that was even close to this magnitude. For a significant number of voters who apparently had been willing to look past their displeasure with the Bush administration's performance, the meltdown was the last straw. 9/11, Iraq, Katrina, now the meltdown. Enough was enough. Time for something different. For a polarized center-right nation struggling with values that drew them to a center-right candidate and performance evaluations that tilted them toward a candidate pledged to "change," the meltdown tipped the decision to performance considerations. ${ }^{23}$ Americans were worn out by crises and wanted change. Barack Obama was the beneficiary of that sentiment. The exit polls showed that 48 percent of voters said that they were "very worried" that the "economic crisis" would hurt their families and 63 percent of them voted for Obama.

\section{A Simple Retrospective Election?}

One might be tempted to conclude that the 2008 election was a simple retrospective election. The electorate was sour on the in-party's performance in office and "turned the bums out." Under the circumstances, there was no way that McCain could have won the election or even made it close. The fundamentals suggested that 2008 would be a Democratic year and it was. It was, however, not so simple.

Though 2008 ultimately was a retrospective election, there was nothing simple about it. A simple retrospective reading of the election misses much of what happened and why the election was decided as it was. The early retrospective perspective does not account for why McCain was nearly even with Obama in the weeks before the conventions, nor does it explain why McCain held a lead over Obama after the conventions. With retrospective conditions so favorable to the Democrats, Obama should have been trouncing McCain both before and after the conventions. But he was not. If the strongly pro-Democratic retrospective perceptions in place before the campaign structured the election, the Wall Street meltdown crisis should have turned a 53 to 54 percent Obama victory into a 58 or 59 percent Obama landslide. But it did not.

The simple retrospective perspective on 2008, that the pre-election pro-Democratic conditions preordained an Obama victory, is not consistent with the course of the campaign that led to the Obama victory. The pre-campaign retrospective evaluations were important, but were muted because of the open seat nature of the contest and political polarization. They were further offset by candidate considerations that favored the moderate-conservative McCain over the northern liberal Obama. Race may or may not have also played a role in this respect. The intervention of the Wall Street meltdown during the campaign recast retrospective evaluations far more negatively and decisively against the Republicans. 


\section{Beyond the Meltdown}

Other factors may have also contributed to Obama's victory, though the extent of their impact appears marginal compared to that of the Wall Street meltdown. Of all the other factors potentially affecting the election, Obama's campaign finance advantage may have been the most potent. In opting out of the public financing system for presidential campaigns, Obama was able to far outspend McCain. The most complete accounting of spending by the two campaigns and their allied party committees indicates that the Obama campaign from June forward spent over one billion compared to the McCain campaign's six hundred million (Rove 2008). By these numbers, Obama outspent McCain by about $\$ 460$ million or more than five times the amount of public funding for a presidential campaign.

There is some evidence that Obama's money advantage made a difference. The Obama campaign had more paid staff, bought more media, and took their campaigns to more states. Although McCain's campaign was hardly run on a shoe-string, it could not afford the kind of intense campaign that they wanted to in all of the potential swing states. Nowhere was this clearer than in the McCain campaign's much covered decision to pull out of Michigan in early October. An initial state-by-state analysis, reported by Karl Rove, found that "Mr. Obama outspent Mr. McCain in Indiana nearly 7 to 1 , in Virginia by more than 4 to 1 , in Ohio by almost 2 to 1 and in North Carolina by nearly 3 to 2 . Mr. Obama carried all four states" (Rove 2008).

It is also clear that Obama's money advantage allowed the campaign to contact more voters and get them to the polls. The national exit poll indicates that $26 \%$ of voters were contacted by the Obama campaign and $18 \%$ by the McCain campaign. The eight percentage point contacting advantage for Obama (coupled with Obama's appeal to younger potential voters who have historically low turnout rates) undoubtedly brought some Obama voters to the polls who might not have made it there otherwise, but probably made no more than a point or so to the vote and is difficult to link to the late-September poll plunge for McCain. ${ }^{24}$

The other factors that have been suggested as additional or alternative contributors to the Obama vote probably made a smaller difference, if any. Other than the question of whether the first debate would be held or postponed, due to McCain suspending his campaign during consideration of the $\$ 700$ billion bailout bill, the debates were quite uneventful. Obama gained 2.6 points in Gallup and less than one point in the Real Clear Politics average from before the first debate to after the third debate. Most of the significant change occurred before the debates.

The selection of Alaska Governor Sarah Palin as John McCain's running mate has also been suggested by some as contributing to McCain's plunge in the polls (Johnston and Thorson 2009). Palin's choice initially energized the conservative base at the Republican Convention, but her initial campaign interviews were widely regarded as disasters. Still, vice presidential candidates have historically made little difference one way or the other. The exit polls shed some light on the issue, though $40 \%$ of voters claimed that the Palin pick was an important factor in determining their votes, these voters split almost evenly between McCain and Obama (51\% McCain to $49 \%$ Obama). ${ }^{25}$ In effect, it would appear that Palin's presence on the ticket may have 
helped McCain as much as it hurt him. There is no question that it won McCain points with the Republican base that had continued to harbor misgivings about his conservative bona fides.

\section{The Deciding Factor}

In comparing the various explanations that have been offered as having been decisive to the outcome of the 2008 election, only the Wall Street meltdown is consistent with three basic facts about the election: that Obama and McCain were close in the polls before the conventions and that McCain held a slight lead after the conventions, that McCain's poll standing dropped 4.5 to 6 points from mid-September to the first week in October, and that President Bush's approval rating also dropped about 8 points from early September to the first week in October. It would seem most plausible that the September declines in McCain's poll standing and Bush's approval ratings are linked. Whatever caused one, also caused the other. To believe otherwise requires that we believe (quite implausibly) that the two views of these two Republicans somehow independently both sank around the same time and to roughly the same extent.

Table 4 presents the four major factors that have been suggested to have been decisive in the 2008 election: the pre-campaign retrospective evaluations that were highly critical of the Bush presidency and a liability for McCain's candidacy, Obama's considerable campaign financing advantage over McCain, the negative reactions to Sarah Palin's post-convention press interviews, and the Wall Street collapse of the financial markets. Each of these four hypothesized explanations is set against the three major and well-documented developments in the campaign and evaluated for whether the proposed explanations are consistent with the campaign evidence.

/Table 4 about here/

If the pre-campaign anti-Bush, anti-Republican referendum take on the election were true, then Obama would have held a commanding lead over McCain from the outset. McCain would have already been well behind in the polls immediately before the first convention and certainly after the second convention. With highly negative retrospective evaluations dominating the electorate's thinking, any further sinking of McCain's poll numbers and Bush's poll numbers would have had the effect of turning a very solid Obama victory into an Obama landslide. Of course this did not happen. Pre-campaign retrospective evaluations did not provide an initial Obama lead. They did not anticipate a late-September poll plummet for McCain nor did they anticipate a concurrent drop in Bush's already low approval ratings. The pre-campaign evaluations are not consistent with these three campaign developments. It is safe to conclude that pre-campaign evaluations of the Bush presidency were not decisive to the election's outcome. ${ }^{26}$

Since Obama's campaign spending advantage and any negative repercussions from Governor Palin's campaign missteps would have had their impact after the conventions, they are both consistent with whatever the competitive situation between Obama and McCain was prior to and immediately following the conventions. Whatever effect on the election they might have had would have taken place during the campaign (though one might have expected a more gradual effect from Obama's money advantage since it was not all spent at one time). The problem with the case for the election turning on either of these factors is that they would be unlikely to have 
concurrently hurt President Bush's already low approval ratings. Though a key aspect of Obama's campaign was to link McCain to Bush, the focus remained McCain, and though McCain might have suffered from some of Palin's early campaign interview problems, it is hard to see how this could have significantly lowered President Bush's approval numbers.

The partisan distribution of the President Bush's approval loss again sheds light on the situation. The change in President Bush's approval ratings from early September to early October are displayed in table 5. If Sarah Palin's problems cost McCain support in any partisan group, it was certainly not in the Republican base. Republicans backed Palin, particularly those Republicans who remained loyal Bush supporters through his troubled second term. While Democrats mocked Palin, those in the conservative Republican base took umbrage to her treatment by the press. Yet the drop in President Bush's approval ratings from early September to early October was mostly in the Republican ranks. Bush's approval ratings among Democrats was at rock-bottom (4 percent) when Palin made a splash at the Republican convention and stayed at rock-bottom (5 percent) when she later became the butt of jokes on Saturday Night Live. President Bush's approval rating among Republicans, who defended Palin through the media onslaught, dropped 16 points in September, from 71 percent to 55 percent. ${ }^{27}$ If Palin had been the reason for the concurrent poll slide of McCain and Bush, we would have either seen previously Bushsupporting Republicans dropping their support for Palin or Bush's poll losses coming from Democrats (and they were so low to begin with that this was impossible). Neither occurred. The outcome of the election did not turn on Palin's problems. ${ }^{28}$

/Table 5 about here/

The turning point in the election was clearly the Wall Street meltdown. It occurred during the campaign and is consistent with the downturn in both McCain's preference poll standing and President Bush's approval standing. The Republicans who had weathered attacks on President Bush in his second term (indicating approval of President Bush in early September) were unlikely to be affected much by the appeals of the well-heeled Obama campaign or by the flurry of negative stories about Sarah Palin. Both could be fended off as too partisan. The Wall Street meltdown, however, could not be so easily dismissed. Like the Hurricane Katrina fiasco, the financial crisis shook the confidence of some Republicans in their party's leadership.

\section{The Exceptional Election in Perspective}

The Wall Street meltdown dominated the campaign and effectively decided the election. As with any event, one must ask whether the reactions of the participants could have altered its impact. While we can never be certain of the counterfactual, what would have happened if a candidate or the President had acted differently or taken different policy stands, with a crisis of this magnitude breaking in the middle of the campaign, it is difficult to imagine that McCain could have done anything differently to have changed the election's outcome.

Even though the Wall Street meltdown made the critical difference to the 2008 election and could easily have happened seven weeks after the election as seven weeks before it, it would be a mistake to dismiss the role that other factors in this election played as well. While McCain might have weathered the poor evaluations of the Bush administration (recall table 3), those 
evaluations placed the party in the position that it could not possibly have also weathered the Wall Street meltdown crisis. Whether by poor judgment, bad luck (faulty intelligence in Iraq and the strike of a once every two-hundred years storm in New Orleans), or decisions to expend political capital for vital public purposes (the war against terrorism), evaluations of the Bush administration's performance offset the party's advantage on values and that allowed the meltdown crisis to make the difference.

While it is true that the timing of the Wall Street meltdown was about as bad as it could have possibly been for the Republicans, it would also be a mistake to consider Obama's election simply a case of bad luck for the Republicans, an accidental Democratic presidency. Liberal Democrats won despite the fact that America remains a right of center nation. Self-described conservatives continued to outnumber self-described liberals among voters by a wide margin (34\% to $22 \%$ in the exit polls, $36 \%$ to $24 \%$ in NES reweighted to the vote). But what matters most is that this self-declared center-right electorate elected Obama and the Democrats. Moreover, Obama and the Democrats exhibited especially strong appeals to both young (beating McCain by two-to-one among those under 30 years old according to both the exit polls and NES) and Latino voters, two groups likely to play larger roles in future elections. What began as the reactions of a crisis-weary electorate and the chance timing of a complicated financial disaster could become something much more.

President Obama and the Democrats in Congress have been given an exceptional opportunity to govern. With the presidency and with large majorities in both chambers of Congress, they will be held responsible for governing in the years ahead. The next few years will reveal what the Democratic Party regards as responsible governance and whether 2008 was simply an outpouring of frustration or a turning point in history. 


\begin{tabular}{|l|c|c|}
\hline \multicolumn{2}{|l|}{ Table 1. Closeness of the Popular Vote in Incumbent and Open Seat Elections, 1868-2004 } \\
\hline $\begin{array}{l}\text { Size of the Two-Party Vote for the } \\
\text { Winning Presidential Candidate }\end{array}$ & Incumbent in the Race & Open Seat Race \\
\hline Near dead-heats (51.5\% or less) & $14 \%(3)$ & $46 \%(6)$ \\
\hline Competitive (51.6\% to 57.0\%) & $45 \%(10)$ & $38 \%(5)$ \\
\hline Landslides (57.1\% or more) & $41 \%(9)$ & $15 \%(2)$ \\
\hline Total & $100 \%(22)$ & $100 \%(13)$ \\
\hline
\end{tabular}

Source: Data compiled from CQ Press (2005). 
Table 2. Presidential Approval Change and Partisanship, 2004 to 2008

\begin{tabular}{|c|c|c|c|}
\hline & Late October 2004 & Mid-July 2008 & Change \\
\hline Overall & 48 & 31 & -17 \\
\hline Democrats & 11 & 7 & -4 \\
\hline Independents & 42 & 28 & -14 \\
\hline Republicans & 93 & 67 & -26 \\
\hline
\end{tabular}

Note: The 2004 approval percentages are from Gallup's October 29-31, 2004 survey. The 2008 precampaign approval percentages are from Gallup's July 10-13, 2008 survey. Source:

http://www.gallup.com/poll/1723/Presidential-Job-Approval-Depth.aspx. 
Table 3. Presidential Approval in July and the In-Party Preference Poll Standing in September, 1948-2008

\begin{tabular}{|c|c|c|}
\hline Election & July Approval & September Preference Poll \\
\hline 1964 & 74 & 69.2 \\
\hline 1956 & 69 & 55.9 \\
\hline 2000 & 59 & 52.1 \\
\hline 1996 & 57 & 60.8 \\
\hline 1972 & 56 & 62.9 \\
\hline 1984 & 52 & 60.2 \\
\hline 1988 & 51 & 54.4 \\
\hline 1960 & 49 & 50.5 \\
\hline 2004 & 47 & 50.5 \\
\hline 1976 & 45 & 40.0 \\
\hline 1968 & 40 & 41.9 \\
\hline 1948 & 39 & 45.6 \\
\hline 1980 & 33 & 48.7 \\
\hline 1952 & 32 & 42.1 \\
\hline 1992 & 31 & 41.9 \\
\hline 2008 & 31 & 52.7 \\
\hline \multicolumn{3}{|c|}{$46 \%$ plus in approval: 9 of 9 were over $50 \%$ in the poll } \\
\hline \multicolumn{3}{|c|}{$46 \%$ minus in approval: 6 of 7 were under $50 \%$ in the poll } \\
\hline
\end{tabular}

Source: The approval data were from the Roper Center and originally collected by Gallup. The preference poll data is from Gallup. 


\begin{tabular}{|c|c|c|c|c|}
\hline \multicolumn{5}{|c|}{ Is the factor's suspected effect consistent with this observed development in the campaign? } \\
\hline \multirow[b]{2}{*}{ Observed Campaign Development } & \multicolumn{4}{|c|}{ Suspected decisive factors tipping the election to Barack Obama } \\
\hline & $\begin{array}{l}\text { Pre-campaign Negative } \\
\text { Retrospective Evaluations } \\
\text { of the Bush Presidency }\end{array}$ & $\begin{array}{l}\text { Obama's Campaign } \\
\text { Spending Advantage }\end{array}$ & $\begin{array}{l}\text { Negative Reactions to } \\
\text { Sarah Palin as VP }\end{array}$ & $\begin{array}{l}\text { Wall Street } \\
\text { Meltdown }\end{array}$ \\
\hline $\begin{array}{l}\text { Close pre-convention polls and } \\
\text { McCain's post-convention poll lead }\end{array}$ & No & Yes & Yes & Yes \\
\hline $\begin{array}{l}\text { Late-September drop in } \\
\text { McCain's preference polls }\end{array}$ & No & Yes & Yes & Yes \\
\hline $\begin{array}{l}\text { Late-September drop in } \\
\text { President Bush's approval ratings }\end{array}$ & No & No & No & Yes \\
\hline
\end{tabular}


Table 5. Presidential Approval Change and Partisanship, Early September to Early October

\begin{tabular}{|c|c|c|c|}
\hline & Early September & Early October & Change \\
\hline Overall & 33 & 25 & -8 \\
\hline Democrats & 4 & 5 & +1 \\
\hline Independents & 31 & 19 & -12 \\
\hline Republicans & 71 & 55 & -16 \\
\hline
\end{tabular}

Source: The approval percentages are from Gallup website: www.gallup.com/poll/116500/PresidentialApproval-Ratings-George-Bush.aspx. The surveys were conducted from September 5-7, 2008 and October 3-5, 2008. 
Figure 1. Democratic and Republican Party Identification among Voters, 1952-2008

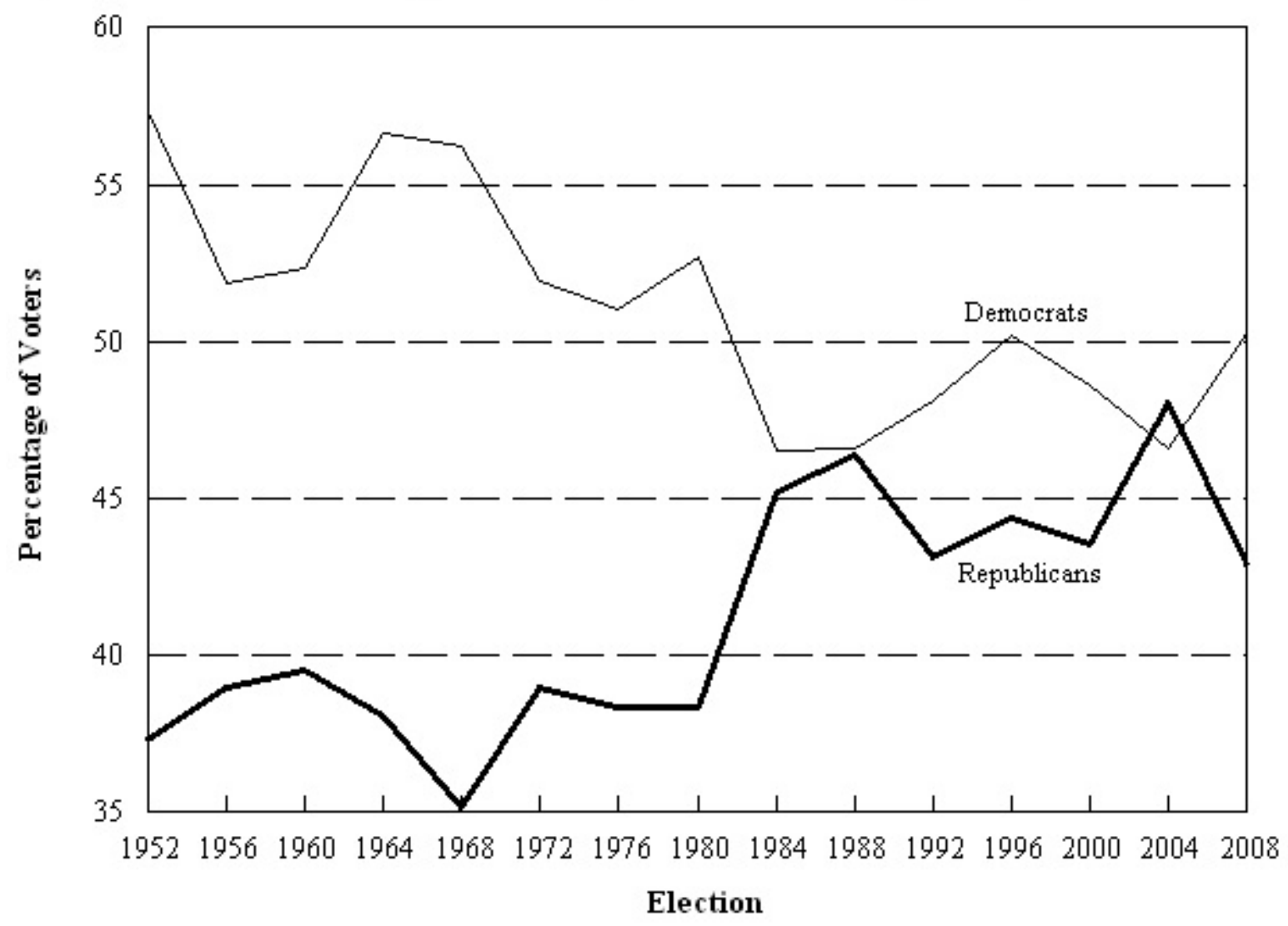

Note: The measure is of NES reported voters. Leaners are counted as partisans. The NES data have been weight. actual divisions of voters and nonvoters (the VEP measure of turnout) and the actual partisan division of the pre 
Figure 2. Percentage of Support for In-Party Candidate John McCain, 2008

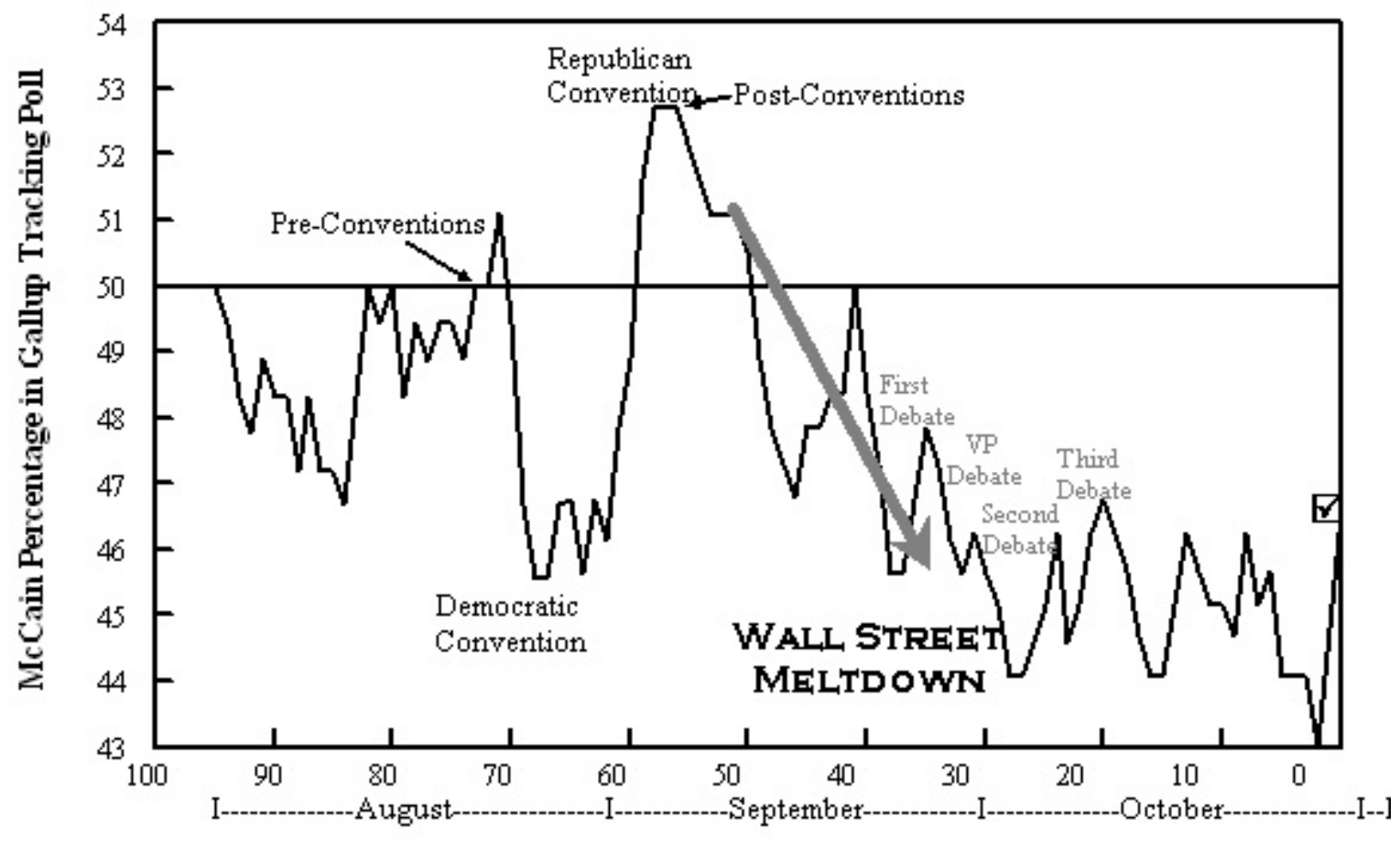

Days Before Election Day

Source: Gallup.com 


\section{References}

Alan I. Abramowitz, "Did the Wall Street Meltdown Change the Election?" Larry J. Sabato's Crystal Ball, 2/5/09. http://www.centerforpolitics.org/crystalball.

. 2006. "Disconnected, or Joined at the Hip?" Red and Blue Nation?: Volume One, Characteristics and Causes of America's Polarized Politics. Pietro S. Nivola and David W. Brady, eds. Washington, D.C.: Brookings, p. 72-85.

. 2008. "Forecasting the 2008 Presidential Election with the Time-for-Change Model," PS: Political Science \& Politics, 41: 691-95.

Abramowitz, Alan I. and Kyle Saunders. 1998. "Ideological Realignment in the U.S. Electorate," Journal of Politics 60:634-52.

Abramowitz, Alan I., Thomas E. Mann, and Larry J. Sabato, 2008. "The Myth of a Toss-Up Election.” From Larry J. Sabato's Crystal Ball website Center for Politics, University of Virginia, July 24, 2008.

Bartels, Larry M. 2000. "Partisanship and Voting Behavior, 1952-1996," American Journal of Political Science 44:35-50.

Bush, George W. 2008. "President Bush Discusses Economy,” September 19, 2008 at 10:45am EDT. http://www.whitehouse.gov/news/releases/2008/09/20080919-2.html.

Campbell, James E. 2008. The American Campaign, Second Edition: U.S. Presidential Campaigns and the National Vote. College Station, TX: Texas A\&M University Press.

. 2006a. "Party Systems and Realignments in the United States, 1868-2004," Social Science History, v.30, issue 3 (Fall 2006), pp. 359-86.

. 2006b. "Polarization Runs Deep, Even By Yesterday's Standards," Red and Blue Nation?: Volume One, Characteristics and Causes of America's Polarized Politics. Pietro S. Nivola and David W. Brady, eds. Washington, D.C.: Brookings. p. 72-85.

. 2001. "The Referendum That Didn't Happen: The Forecast of the 2000 Presidential Election," PS: Political Science and Politics. 34(1): 33-38.

. 2000. "The Science of Forecasting Presidential Elections," In James E. Campbell and James C. Garand (Eds.), Before the Vote: Forecasting American National Elections (pp. 169-187).Thousand Oaks, CA: Sage Publications.

CQ Press. 2005, Guide to U.S. Elections, Fifth Edition. Washington, D.C.: CQ Press. 
Fiorina, Morris P. with Samuel J. Abrams and Jeremy C. Pope. 2006. Culture War? The Myth of a Polarized America. New York: Pearson, Longman.

Hetherington, Marc J. 2001. "Resurgent Mass Partisanship: The Role of Elite Polarization," American Political Science Review 95:619-31.

Holbrook, Thomas M. 2008. "Incumbency, National Conditions, and the 2008 Presidential Election," PS: Political Science and Politics. 41(4): 709-12.

Jacobson, Gary C. 2007. A Divider, Not a Uniter: George W. Bush and the American People. New York: Pearson, Longman.

Johnston, Richard and Emily Thorson. 2009. "The Economy, the Candidates, and the 2008 Campaign," presented at the Annual Meeting of the American Political Science Association, Toronto, Canada.

Keith, Bruce E., David B. Magleby, Candice J. Nelson, Elizabeth Orr, Mark C. Westlye, and Raymond E. Wolfinger.1992. The Myth of the Independent Voter. Berkeley, CA: University of California Press.

Leip, Dave. 2009. Dave Leip's Atlas of Presidential Elections (http://uselectionatlas.org/).

Lewis-Beck, Michael S. and Charles Tien. 2008. "The Job of President and the Jobs Model Forecast: Obama for '08,' PS: Political Science and Politics. 41(4): 687-90.

MacKuen, Michael B., Robert S. Erikson, and James A. Stimson, 1989. "Macropartisanship," American Political Science Review 83: 1125-42.

Mayhew, David R. 2008. "Incumbency Advantage in U.S. Presidential Elections: The Historical Record,” Political Science Quarterly, v.123, n.2. p.201-228.

Meffert, Michael F., Helmut Norpoth, and Anirudh V. S. Ruhil, 2001. "Realignment and Macropartisanship," American Political Science Review, 95: 4, 953-62.

Nadeau, Richard, and Michael S. Lewis-Beck. 2001. National Economic Voting in U.S. Presidential Elections. Journal of Politics, 63, 159-181.

Norpoth, Helmut. 2008. “On the Razor's Edge: The Forecast of the Primary Model,” PS: Political Science and Politics. 41(4): 683-86. . 2002. "On a Short-Leash: Term Limits and the Economic Voter." In Han Dorussen and Michael Taylor (Eds.), Economic Voting (pp. 121 36). Oxford: Routledge.

. 1987. "Under Way and Here to Stay: Party Realignment in the 1980s?" Public Opinion Quarterly 51: 376-391. 
Paulson, Arthur. 2007. Electoral Realignment and the Outlook for American Democracy. Boston: Northeastern University Press.

Rove, Karl. 2008. “Obama’s Money Advantage,” Polling News and Notes, December 11, 2008. Karl Rove \& Company. http://www.rove.com/election.

Sabato, Larry J. 2009. "The 2008 Election in Perspective: Just What We Would Have Expected," Larry J. Sabato’s Crystal Ball, 1/15/09. http://www.centerforpolitics.org/crystalball.

Sowell, Thomas. 2009. The Housing Boom and Bust. New York: Basic Books. 


\section{Endnotes}

1.This paper significantly expands upon, revises, and extends a preliminary analysis presented in The Forum: A Journal of Applied Research in Contemporary Politics, Volume 6 / Issue 4 (October 2008) http://www.bepress.com/forum/vol6/iss4/

2. These election data are from CQ Press (2005) and Dave Leip's Atlas of Presidential Elections (http://uselectionatlas.org/).

3. These data are from PollingReport,com at http://www.pollingreport.com/right.htm.

4. These data are from PollingReport.com at http://www.pollingreport.com/iraq.htm.

5. These data are from the U.S. Bureau of Economic Analysis at http://www.bea.gov/.

6. These data are from the Energy Information Administration in "U.S. Regular All Formulations Retail Gasoline Prices (Cents per Gallon) Department of Energy" at http://tonto.eia.doe.gov/dnav/pet/hist/mg rt usm.htm.

7. The presidential approval for 2008 used throughout are from Gallup at http://www.gallup.com/poll/1723/Presidential-Job-Approval-Depth.aspx.

8. The two-party popular votes were computed from data in CQ Press (2005).

9. Since 1868, there have been 16 incumbents who ran and won their election. Their average winning two-party vote was $56.6 \%$. The average winning vote for open-seat winners in this period was $53.1 \%$.

10. Democratic party identification gains are evident in both the national exit polls and National Election Study data. In the exit poll data, the party identification gap, not including leaning independents as partisans, was 7 points (39\% Democrats and 32\% Republicans). There had been no gap in 2004. The exit poll data used throughout were obtained from http://www.cnn.com/ELECTION/2008/results/polls/\#val=USP00p1. The 2008 NES data with their prescribed weights slightly over-represented Obama voters. The data were reweighted to correct for this. The weights used with party identification were .987 for Obama voters, 1.026 for McCain voters, and .760 for third party voters.

11. Despite the ideological sorting of the realignment and the fact that conservatives outnumber liberals, Democrats continue to outnumber Republicans. This is possible because of the stronger drawing power of Democrats with nonideologicals and moderates. This may reflect the strength of Democrats with less educated voters who are more likely to be unaware of ideological terminology, though Democrats also fare better than Republicans among self-described moderates. 
12. The mood data are from James Stimson's website http://www.unc.edu/ ijstimson/index.html. Stimson's mood index of public opinion is a thermostatic measure. This means that it indicates whether the current administration as perceived by the public is too liberal or too conservative. The mood index, though often misused, does not indicate the public's ideology or its ideal extent of liberalism or conservatism. As Stimson's alternative measure of ideology indicates, the public going into the 2008 election may have favored a less conservative government than the status quo, but was at the same time fairly conservative in their preferences.

13. For the contrary view, that Americans are not polarized see Fiorina (2006). The data used here are from the National Election Study's Cumulative File.

14. NES data (unadjusted) report that about half of Democrats and Republicans voting in their parties' primaries voted for their parties' eventual nominees. Almost all of the partisans who voted for their party's nominee in the primaries also voted for him in the general election. Among those who had not voted for the eventual nominee, 88 percent in both parties loyally voted for their party's candidate in November. The exit polls produce similar differences among Democrats (but did not ask about party unity among Republicans).

15. For a view that race would cause a disjunction between retrospective evaluations and both the preference polls and the election results, see Lewis-Beck and Tien 2008.

16. The ADA data are from http://www.adaction.org/pages/publications/voting-records.php and the ACU data are from http://www.acuratings.org/.

17. It is interesting to note that the exit poll did not even ask about McCain's position on the issues as being too liberal or too conservative. This might be interpreted as the ultimate testimony to McCain's centrism.

18. Throughout the campaign, the Gallup data were obtained at http://www.gallup.com/Home.aspx and the Real Clear Politics averages of the polls were collected from http://www.realclearpolitics.com/polls/.

19. The higher turnout rate of registered Republicans compared to registered Democrats is evident in National Election Study data for every election from 1952 to 2008. According to NES data, Republicans again had a turnout advantage over Democrats. In the NES survey, 86 percent of Republicans reported that they voted compared to 78 percent of Democrats. An examination of the Democratic vote and the Democrat's standing in the early September Gallup Poll of registered voters in elections from 1948 to 2004 indicates that a Democrat candidate needs to have 51.5 percent in the polls to be expected to receive 50 percent of the vote.

20. Stimpson's data were obtained from his website at http://www.unc.edu/ jstimson/.

21. The consumer confidence ratings are from Gallup at http://www.gallup.com/poll/1609/Consumer-Views-Economy.aspx. Respondents are asked, "How would you rate economic conditions-as excellent, good, only fair, or poor?" 
22. These survey data are from PollingReport.com's Business Issues in the News on November 11, 2008 at http://www.pollingreport.com/business.htm.

23. A similar but competing explanation of McCain's strong pre and post-convention poll standings relates to race rather than ideology. Lewis-Beck and Tien (2008), for instance, contend that racial prejudice caused support for Obama to be less than what it would normally be in such a Democratic year. This reasoning suggests that racial biases prevented some people from supporting Obama and that these were only overcome by their reactions to the Wall Street meltdown.

24. Of those contacted by only one party, $80 \%$ reported voting for the contacting candidate. Of course, this may be largely a selection effect since the opposite party is unlikely to waste resources contacting those unlikely to vote for it. On the other hand, the contacting party is also unlikely to waste resources on those who are sure to vote for it. It is probably safe to say that this contacting makes a marginal difference in getting out the vote.

25. Assuming that those thinking Palin was important to their decision are representative of the partisan distribution in the electorate, the even split suggests no Palin effect. If, however, Republicans were disproportionately among those thinking Palin was important to their votes, then the even division would indicate that Palin had been a liability-since one would expect a much stronger McCain vote from them. In short, a determination of Palin's effect, if any, awaits multivariate analysis.

26. Many of the election forecasting models were based on simple pre-campaign retrospective voting assumptions (Abramowitz 2008). These forecasts appeared to be accurate in 2008 because they were luckily flawed in two important offsetting ways. First, in not taking the open seat aspect of the election into account, they predicted a stronger vote for Obama than was historically warranted. However, second, because of the Wall Street meltdown that they (like everyone else) did not anticipate, the vote actually moved in late September toward this stronger vote for Obama. This made their models appear more accurate than they really were. Since none of these models anticipated the voter movement resulting from the meltdown (and several included an economic indicator actually suggesting average economic conditions), the pro-Obama meltdown effects added to the pre-campaign pro-Obama political climate (undiscounted for the open seat situation) should have produced an Obama landslide. The fact that this is not what happened indicates that these models should have been discounting the pre-campaign climate because of the open seat aspect of the election.

27. As table 5 shows, Bush also lost some ground in September from independents. However, since independents are such a small portion of those who vote, these losses did not mean much. Since Republican identifiers outnumbered pure independents by more than six to one (42.9 percent to 6.7 percent), it was the loss of approval among Republicans that accounts for most of the overall approval loss for President Bush in September.

28. An analysis of daily polls is unlikely to reveal much about the effects of either Sarah Palin or the Wall Street meltdown on the election. We know that most voters do not closely monitor 
either economic news or news about vice presidential candidates very closely, even during campaigns. We also know that there is some unknown lag in whatever seeps through to voters and that the length of the lag may vary with the gravity of the news and may also be cumulative. 